\title{
In vitro and in vivo antimalarial activity and cytotoxicity of extracts, fractions and a substance isolated from the Amazonian plant Tachia grandiflora (Gentianaceae)
}

\author{
Luiz Francisco Rocha e Silva ${ }^{1,2,3}$, Emerson Silva Lima ${ }^{2}$, Marne Carvalho de Vasconcellos ${ }^{2}$, \\ Ellen Suzany Pereira Aranha ${ }^{2}$, David Siqueira Costa ${ }^{1,3}$, Elba Vieira Mustafa, ${ }^{1,2}$, \\ Sabrina Kelly Reis de Morais ${ }^{1,2}$, Maria das Graças Costa Alecrim ${ }^{4}$, Sergio Massayoshi Nunomura', \\ Lena Struwe ${ }^{5}$, Valter Ferreira de Andrade-Neto ${ }^{6}$, Adrian Martin Pohlit ${ }^{1 /+}$
}

\footnotetext{
'Laboratório de Princípios Ativos da Amazônia, Coordenação de Tecnologia e Inovação, Instituto Nacional de Pesquisas da Amazônia, Manaus, AM, Brasil ${ }^{2}$ Universidade Federal do Amazonas, Manaus, AM, Brasil ${ }^{3}$ Centro Universitário do Norte, Manaus, AM, Brasil ${ }^{4}$ Fundação de Medicina Tropical Doutor Heitor Vieira Dourado, Manaus, AM, Brasil ${ }^{5}$ Rutgers, The State University of New Jersey, New Brunswick, NJ, USA ${ }^{6}$ Universidade Federal do Rio Grande do Norte, Natal, RN, Brasil
}

Tachia sp. are used as antimalarials in the Amazon Region and in vivo antimalarial activity of a Tachia sp. has been previously reported. Tachia grandiflora Maguire and Weaver is an Amazonian antimalarial plant and herein its cytotoxicity and antimalarial activity were investigated. Spectral analysis of the tetraoxygenated xanthone decussatin and the iridoid aglyone amplexine isolated, respectively, from the chloroform fractions of root methanol and leaf ethanol extracts was performed. In vitro inhibition of the growth of Plasmodium falciparum Welch was evaluated using optical microscopy on blood smears. Crude extracts of leaves and roots were inactive in vitro. However, chloroform fractions of the root and leaf extracts [half-maximal inhibitory concentration $\left(I C_{50}\right)=10.5$ and $35.8 \mu \mathrm{g}$ / $m L$, respectively] and amplexine $\left(I C_{50}=7.1 \mu \mathrm{g} / \mathrm{mL}\right)$ were active in vitro. Extracts and fractions were not toxic to type MRC-5 human fibroblasts $\left(I C_{50}>50 \mu \mathrm{g} / \mathrm{mL}\right)$. Water extracts of the roots of $\mathrm{T}$. grandiflora administered by mouth were the most active extracts in the Peters 4-day suppression test in Plasmodium berghei-infected mice. At $500 \mathrm{mg} /$ $\mathrm{kg} /$ day, these extracts exhibited $45-59 \%$ inhibition five to seven days after infection. T. grandiflora infusions, fractions and isolated substance have potential as antimalarials.

Key words: amplexine (djalonenol) - decussatin - Plasmodium falciparum - Plasmodium berghei - human fibroblasts

Geographic distribution of Tachia spp - Tachia Aubl. (Gentianaceae) was first described by the botanist Aublet in 1775 based on plants collected in French Guyana. Before 1975, only the type species Tachia guianensis Aubl. was known. Recent studies show that T. guianensis occurs only in French Guyana and Suriname (Peters et al. 2005). Today, it is accepted that Tachia is comprised of 13 closely related understory shrubs or small tree species (Peters et al. 2005), which occur also in the wet forests of the Amazon Basin and the lower elevations of mountainous areas of Peru, Ecuador, Colombia, Venezuela and Brazil (7 species) and Panama (1 species) (Peters et al. 2005). Tachia grandiflora (Maguire \& Weaver 1975),

doi: 10.1590/0074-0276108042013017

Financial support: CNPq (520354/99-0 \& 550260/01-3), CNPq-

Brazilian Malaria Network, CNPq-Bionorte Program,

Bioamazonia-BASA-FEPAD Contract

TCMS , LFRS and AMP were supported by scholarships from the PIBIC/INPA, PCI/INPA and PQ/CNPq, respectively.

ESL is a member of INCT-Redoxoma (MCT/CNPq).

+ Corresponding author: ampohlit@inpa.gov.br

Received 11 December 2012

Accepted 26 March 2013 studied herein, is widespread in wet tropical forests of the central and eastern part of the Amazon Basin and northwestern South America and from French Guyana and Suriname in the north to central parts of the state of Amazonas (AM) in Brazil to the west and south [see map in Peters et al. (2005)].

Traditional use of Tachia spp as antimalarials - Ethnobotanical and ethnopharmacological publications have described the traditional uses of Tachia spp as antimalarials and febrifuges in The Guyanas, Brazil, Colombia and Peru (Milliken 1997). However, in many Brazilian (Carvalho \& Krettli 1991, Brandão et al. 1992, Milliken 1997, Mors et al. 2000, Krettli et al. 2001), Colombian (Schultes \& Raffauf 1990) and Peruvian (Milliken 1997) studies the plants collected are incorrectly identified as the type species of the genus, T. guianensis Aubl.

T. grandiflora - We became interested in studying the local caferana plant, T. grandiflora, based on earlier reports by the Dr Antoniana Krettli group (Oswaldo Cruz Foundation, state of Minas Gerais, Brazil) in which the water extract of roots of a Tachia sp. exhibited significant in vivo activity in a mouse model of malaria. Tachia spp are rare, sparsely populated plants in the Amazon forests. We initially conducted studies on the propagation of this plant from stem cuttings (Silva et al. 2006). Pio Corrêa (1926) reported that caferana extracts were toxic. Polar 
extracts of T. grandiflora were not toxic to Artemia franciscana in the brine shrimp assay (Quignard et al. 2003). In another study, extracts of T. grandiflora at $500 \mu \mathrm{g} / \mathrm{mL}$ exhibited moderate toxicity (7-64\% lethality) to larvae of Aedes aegypti (Pohlit et al. 2004). Also, extracts of $T$. grandiflora were highly active inhibitors of the growth of cancer tumour cell lines (Pohlit et al. 2007).

Antimalarial plants such as $T$. grandiflora are potential sources of drug leads against Plasmodium spp (Andrade-Neto et al. 2007, Schmidt et al. 2012a, b). Recently, we isolated the tetra-oxygenated xanthone decussatin (1) and a rare seco-iridoid monoterpene aglycone, djalonenol (amplexine) (2), from T. grandiflora (Pohlit et al. 2012). In the present work, the in vitro and in vivo antiplasmodial activity and cytoxicity of the extracts, fractions and chemical components of the leaves and roots of the central Amazonian caferana plant, T. grandiflora, were investigated. Spectroscopic characterisation of the isolates 1 and 2 is also presented.

\section{MATERIALS AND METHODS}

Chemicals - All solvents used for extraction, partitioning and chromatography were fractionally distilled prior to use. Solvents for NMR were purchased from Sigma-Aldrich (St. Louis, USA).

Instrumentation - Medium pressure liquid chromatography (MPLC) was performed using a Büchi System with Pump model 688, Gradient Former model 687, ultraviolet visible spectroscopy and fraction collector model 684 and a normal phase column with 40-63 $\mu \mathrm{m}$ particle size. ${ }^{1} \mathrm{H}-\mathrm{NMR},{ }^{13} \mathrm{C}-\mathrm{NMR}$, DEPT $135,{ }^{1} \mathrm{H}-{ }^{1} \mathrm{H}$ COSY and HMQC spectra were acquired on a Bruker DPX $300(300 \mathrm{MHz})$ in $\mathrm{CDCl}_{3} / \mathrm{TMS}$ or $\left(\mathrm{CD}_{3}\right)_{2} \mathrm{CO} / \mathrm{TMS}$. FT-IR spectra were acquired on a Bomem model M 102 spectrometer. Electronic ionization-gas chromatography-mass spectrometry (EI-GC-MS) was performed on a Hewlett-Packard HP 5890 series gas chromatograph coupled to mass detector HP 5971 operating at an ionization energy of $70 \mathrm{eV}$.

Plant material - Plant materials were collected in September and October, 2000 in National Institute for Amazonian Research's (INPA) Campina and Adolpho Ducke Forest Reserves which are located in greater Manaus, AM. Voucher specimens were deposited at the INPA Herbarium under the accessions 208104 (collector AM Pohlit) and 205948 (collector AM Pohlit). Identification of the plant samples as T. grandiflora Maguire and Weaver (Gentianaceae) was corroborated by LS (co-author of the present paper). Roots and mature leaves were separately dried in the shade and ground to fine powders.

Extraction and isolation of 1 - Dried, powdered roots were continuously extracted in a Soxhlet apparatus with methanol $(3 \times 6 \mathrm{~h})$. The extracts were combined and evaporated under vacuum using a rotary evaporator with heat bath $\left(\leq 40^{\circ} \mathrm{C}\right)$ and then freeze-dried. The resulting dry methanol extract $(5 \mathrm{~g})$ was dissolved in methanoldistilled water (9:1) and partitioned with hexanes, then chloroform. After total evaporation, the chloroform fraction was analysed by thin-layer chromatography (TLC) and tested positively for the presence of alka- loids (Dragendorf reagent) and phenolic (ferric ion test) compounds. The chloroform fraction $(950 \mathrm{mg}$ ) was submitted to normal-phase column chromatography. After combination of initial fractions based on TLC profiles, 10 fractions were obtained. Fraction 8 contained yellowish white crystals in the form of small plates or needles of $1(24 \mathrm{mg})$. These procedures were partially described in Pohlit et al. (2012).

Spectral analysis and identification of $1-{ }^{1} \mathrm{H},{ }^{13} \mathrm{C}$ NMR and IR data obtained of the crystals obtained above were consistent with a structure containing a phenolic $\mathrm{OH}\left(\delta_{\mathrm{H}} 13.2 ; 3432 \mathrm{~cm}^{-1}\right)$ forming an intramolecular H-bond with the $\mathrm{C}=\mathrm{O}$ of a xanthone $\left(\delta_{\mathrm{C}} 181.1\right.$; $\left.1608 \mathrm{~cm}^{-1}\right)$. Also, three singlets $\left(\mathrm{CH}_{3} \mathrm{O}\right)$, a pair of doublets characteristic of meta-coupled aromatic Hs $(J=2$ $\mathrm{Hz}$ ) and a pair of doublets characteristic of ortho-coupled aromatic Hs $(J=9 \mathrm{~Hz})$ were further evidence for a 1,3,7,8-tetrasubstituted xanthone. The EI-MS spectra of 1 exhibited ions $\mathrm{m} / \mathrm{z} 302\left[\mathrm{M}^{+}\right]$and $287\left[\left(\mathrm{M}^{+}-15\right)\right.$, base peak]. Comparison of these data with ${ }^{1} \mathrm{H}$ and ${ }^{13} \mathrm{C}$ NMR spectral data in the literature (Tchamo et al. 2000, Dua et al. 2004) led to the identification of this compound as 1-hydroxy-3,7,8-trimethoxyxanthone whose trivial name is decussatin (1) (Fig. 1).

Extraction and isolation of 2 - Dried, powdered leaves $(211 \mathrm{~g})$ of T. grandiflora were macerated in ethanol $(2 \times$ $1 \mathrm{wk})$. After total evaporation, $49 \mathrm{~g}$ of the dry ethanol extract were dissolved in methanol-water (9:1) and this mixture was partitioned with hexanes. $\mathrm{H}_{2} \mathrm{O}$ was added to the methanol-distilled water fraction to yield a $30 \%$ water solution, which was partitioned with chloroform. Hexanes fractions were combined, rotary evaporated and then freeze-dried to yield a dry, combined hexanes fraction $(4.35 \mathrm{~g}, 8 \% \mathrm{w} / \mathrm{w}$ based on ethanol extract). A similar procedure applied to the chloroform fractions yielded a dry, combined chloroform fraction (13.62 g, 27.8\%). Dry chloroform fraction $(10 \mathrm{~g})$ was dissolved in chloroform and chromatographed on a column of silica gel 60 (Merck, $0.063-0.200 \mathrm{~mm}, \mathrm{~h} \times \mathrm{d}=10 \times 7 \mathrm{~cm})$. The column was eluted first with hexanes, then with a gradient of increasing polarity of acetone in chloroform. After combination based on TLC, five fractions resulted. Fraction $2(2 \mathrm{~g})$ was chromatographed on a column of silica gel $60 \mathrm{~h} \times$ $\mathrm{d}=30 \times 4.5 \mathrm{~cm}$ ) using a gradient of increasing polarity
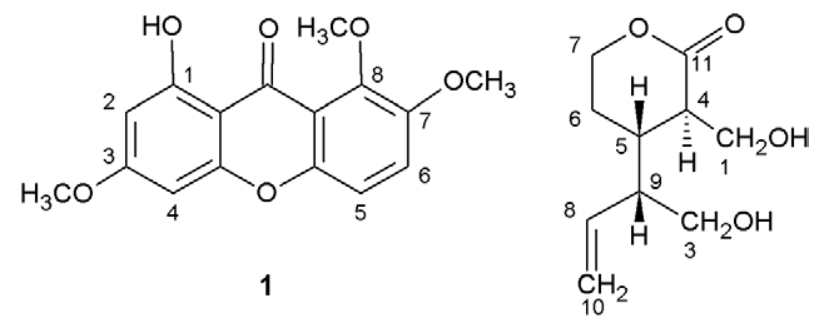

2

Fig. 1: decussatin (1-hydroxy-3,7,8-trimethoxyxanthone) (1) and amplexine (djalonenol, tetrahydro-3-(hydroxymethyl)-4-[1-(hydroxymethyl)-2 -propenyl]-2H-pyran-2-one) (2) isolated from Tachia grandiflora. 
of acetone in chloroform. After combining, nine fractions were obtained. Fraction 7 (323 mg) was separated by MPLC on a column of silica gel $(\mathrm{h} \times \mathrm{d}=25.0 \times 2.15$ $\mathrm{cm})$ using hexanes, then hexanes-chloroform-isopropanol (80:16:4) and finally chloroform-isopropanol (80:20). Six fractions were obtained and fraction $5(101 \mathrm{mg})$ was separated on a column of Sepak silica (Varian, $h \times d=30$ $\times 2 \mathrm{~cm}$ ) eluted with hexanes, then a gradient of hexanesdiethyl ether-isopropanol and finally isopropanol. Three fractions were obtained and fraction 3 (46 mg) was further purified by preparative TLC to yield $2(25 \mathrm{mg})$ as a clear liquid $\left[\mathrm{R}_{\mathrm{F}}=0.60\right.$, ethyl acetate-methanol (2:1)] which, was identified as the secoiridoid monoterpene amplexine (or djalonenol) based on its spectral properties. This isolation procedure was partially described in Pohlit et al. (2012).

Spectral analysis and identification of 2 - From the ${ }^{1} \mathrm{H}-\mathrm{NMR},{ }^{13} \mathrm{C}-\mathrm{NMR},{ }^{1} \mathrm{H}-{ }^{1} \mathrm{H}-\mathrm{COSY}$ and HMQC spectra (in $\mathrm{CDCl}_{3}$ ) of clear liquid 2 (isolated from the leaves of T. grandiflora), a terminal olefin was evidenced by coupled signals centered at $\delta 5.21(2 \mathrm{H}, \mathrm{H}-10 \mathrm{a} / \mathrm{H}-10 \mathrm{~b})$ and $\delta$ $5.69(1 \mathrm{H}, \mathrm{H}-8)$ and ${ }^{1} \mathrm{H}-\mathrm{NMR}$ and ${ }^{1} \mathrm{H}-{ }^{1} \mathrm{H}-\mathrm{COSY}$ provided the connectivity through the following correlations: $\delta 5.69(\mathrm{H}-8)$ and $\delta 2.39(\mathrm{H}-9), \delta 2.39(\mathrm{H}-9)$ and $\delta 3.62$ $(\mathrm{H}-3 \mathrm{a}) / 3.70(\mathrm{H}-3 \mathrm{~b}), \delta 2.39(\mathrm{H}-9)$ and $\delta 2.22(\mathrm{H}-5), \delta 2.22$ $(\mathrm{H}-5)$ and $\delta 2.75(\mathrm{H}-4) / \delta 1.78(\mathrm{H}-6 \mathrm{a}) / \delta 1.94(\mathrm{H}-6 \mathrm{~b}), \delta 1.78$ $(\mathrm{H}-6 \mathrm{a})$ and $\delta 1.94(\mathrm{H}-6 \mathrm{~b})$ and $\delta(\mathrm{H}-7 \mathrm{a}) / \delta 4.28(\mathrm{H}-7 \mathrm{~b})$. The presence of the lactone function was evidenced by signals at $\delta 175.0(\mathrm{C}-11)$ and $\delta 68.9(\mathrm{C}-7)$ in the ${ }^{13} \mathrm{C}-\mathrm{NMR}$ spectra and by the intense infrared band at $1712 \mathrm{~cm}^{-1}$. Using direct insertion on probe EI-MS, the MS spectrum of $2\left(\mathrm{C}_{10} \mathrm{H}_{16} \mathrm{O}_{4}, \mathrm{MW} 200\right)$ exhibited a low intensity ion at $m / z 201\left[(\mathrm{M}+\mathrm{H})^{+}\right]$and ions at $m / z 170$ (loss of $\mathrm{H}_{2} \mathrm{C}$ $=\mathrm{O}$ due to McLafferty Rearrangement) and $\mathrm{m} / \mathrm{z} 152$ (further loss of $\mathrm{H}_{2} \mathrm{O}$ ). Comparison of NMR and other data with literature data (Rasoanaivo et al. 1994, Onocha et al. 1995) allowed for the identification of compound 2 as amplexine [djalonenol, tetrahydro-3-(hydroxymethyl)-4 -[1-(hydroxymethyl)-2-propenyl]-2H-pyran-2-one].

Antimalarial activity - In vitro antiplasmodial assay - Chloroquine, pyrimethamine and cycloguanil-resistant Plasmodium falciparum K1 strain from the Center for Disease Control (CDC) (USA) was used to test antiplasmodial activity of extracts and fractions. P. falciparum W2-Indochina strain (CDC, USA) was used to test antiplasmodial activity of compound 2 . The parasites were maintained in continuous culture at $37^{\circ} \mathrm{C}$ using $\mathrm{A}+$ blood cells in RPMI-1640 culture medium, which was enriched with $10 \%$ blood plasma (complete medium) and atmosphere of $5 \% \mathrm{CO}_{2}, 5 \% \mathrm{O}_{2}$ and $90 \% \mathrm{~N}_{2}$. Trophozoite-stages in sorbitol-synchronised blood (Lambros \& Vanderberg 1979) were cultured at 1-2\% parasitaemia and 2.5\% haematocrit and then incubated with medium containing various concentrations of sample, either chloroquine diluted in culture medium - at standard concentrations (Rieckmann et al. 1978, WHO 2001) - or extracts, fractions $\left(0.0032-50 \mu \mathrm{g} \mathrm{mL}^{-1}\right)$ and compound $2(0.0005-50$ $\mu \mathrm{g} / \mathrm{mL}$ ) in 10 -fold serial dilutions were applied to microplate wells in triplicate. Negative (untreated) con- trol wells having a $1 \%$ final concentration of dimethyl sulfoxide (DMSO) in culture medium were prepared in triplicate. The initial conditions of the test were adjusted so as to be similar to conditions used for parasite culture. The microplate was placed in an acrylic incubator where the mixture of gases used in culture was added and incubation occurred at $37^{\circ} \mathrm{C}$ for $48 \mathrm{~h}$. Then thin smears on microscope plates were prepared from each well and optical microscopy was used to quantify the number of surviving parasites per 2,000 red blood cells. Growth of parasites in contact with extracts, fractions and isolated substance was compared to that of negative controls and the inhibition of parasite growth was expressed as a percentage. The half-maximal inhibitory concentration $\left(\mathrm{IC}_{50}\right)$ responses were estimated by the probit method.

Cytotoxicity evaluation using the alamarBlue Assay MRC-5 (human fibroblast) cells seeded in 96-well plates $\left(10^{4}\right.$ cells per well) were treated with substances and the alamarBlue ${ }^{\mathrm{TM}}$ Assay was performed using the method of Ahmed et al. (1994). Briefly, after 24 h of culture, the extracts and fractions were individually dissolved in DMSO and added to each well (at well or final concentrations of $50 \mu \mathrm{g} / \mathrm{mL}$ ) and incubated for $48 \mathrm{~h}$. Doxorubicin $(5 \mu \mathrm{g} / \mathrm{mL})$ was used as positive control. Negative controls (blanks) received the same amount of DMSO and had the same final DMSO concentrations as samples ( $0.1 \%)$. Two hours before the end of the incubations, $10 \mu \mathrm{L}$ of alamarBlue $^{\mathrm{TM}}$ was added to each well. The fluorescent signal was monitored with a multiplate reader (DTX800, Beckman Coulter, Inc) using a 530-560 nm excitation wavelength range and $590 \mathrm{~nm}$ emission wavelength. The fluorescent signal generated from the assay was proportional to the number of living cells in the sample, according to the specifications of the manufacturer.

Statistical analysis - Data generated in the alamarBlue $^{\mathrm{TM}}$ Assay are presented as mean \pm standard error of the mean. $\mathrm{The}^{\mathrm{IC}} \mathrm{C}_{50}$ values and their $95 \%$ confidence intervals were obtained by nonlinear regression using the GRAPHPAD program (Intuitive Software for Science, San Diego, CA).

Animals and ethical approval - Adult Webster Swiss albino mice ( $26 \pm 2 \mathrm{~g}$ weight) were used for the antimalarial and toxicity tests and received water and food ad libitum. In vivo tests were performed using Guidelines for Ethical Conduct in The Care and Use of Animals of Federal University of Rio Grande do Norte (CEUA 043/2010).

In vivo antiplasmodial activity - In vivo antimalarial activity was evaluated using Plasmodium berghei NK65 strain (drug-sensitive). This strain was maintained by successive passages of blood forms from mouse to mouse. The test protocol is based on the Peters 4-day suppressive test. Female Webster Swiss mice weighing $26 \pm 2 \mathrm{~g}$ were used in this study. Animals were infected intraperitoneally with $0.2 \mathrm{~mL}$ of infected blood suspension containing $1 \times 10^{5}$ parasitised erythrocytes and randomly divided into groups of three individuals. Test groups were treated orally and subcutaneously at doses of $500 \mathrm{mg} / \mathrm{kg} / \mathrm{day}$ of extracts. Positive control groups 
received a dose of $10 \mathrm{mg}$ chloroquine $/ \mathrm{kg} / \mathrm{day}$ orally or subcutaneously and negative control groups received 0.2 $\mathrm{mL}$ of $2 \%$ DMSO or saline. The animals were treated for four days starting $24 \mathrm{~h}$ after inoculation with $P$. berghei. On days 5 and 7 after parasite infection, blood smears were prepared from all mice, fixed with methanol, stained with Giemsa, then microscopically examined (1,000X magnification). Parasitaemia was determined in coded blood smears by randomly counting 2,000-4,000 erythrocytes in the case of low parasitaemias $(\leq 10 \%)$ or up to 1,000 erythrocytes in the case of higher parasitaemias. Overall mortality was monitored daily in all groups during a period of four weeks following inoculation. The difference between the average parasitaemia of control groups $(100 \%)$ and test groups was calculated as a percentage of parasite growth suppression (PGS) according to the equation $\mathrm{PGS}=100 \times(\mathrm{A}-\mathrm{B}) / \mathrm{A}$, where $\mathrm{A}$ is the average parasitaemia of the negative control group and B corresponds to the parasitaemia of the test group.

\section{RESULTS}

Chemistry - Since infusions of T. grandiflora are used in traditional medicine, polar extracts were prepared by hot extraction with water (infusion), hot continuous extraction with methanol in a soxhlet apparatus and room temperature maceration in ethanol. We detected alkaloids in the chloroform fractions obtained from the methanol extracts of roots, however, alkaloids were not isolated. Instead, needles or plates of 1 were isolated from the roots of $T$. grandiflora and a rare isolate 2 was isolated as a non-viscous, clear liquid, from the leaves of this plant. As detailed above, the identification of both substances was straight-forward based on spectral data and comparison with data in the literature for each compound.

Cytotoxicity to human fibroblasts - Extracts and fractions of T. grandiflora were evaluated for toxicity against human fibroblast cells (MCR-5) using the antitumor drug doxorubicin as positive control. At a concentration of $50 \mu \mathrm{g} / \mathrm{mL}$, after $48 \mathrm{~h}$ of treatment, methanol and water extracts of roots, ethanol extracts of leaves, chloroform fractions of leaves and chloroform fractions

\section{TABLE I}

In vitro median inhibition concentrations $\left(\mathrm{IC}_{50} \pm\right.$ standard deviation) of extracts and fractions of Tachia grandiflora against K1 strain of Plasmodium falciparum

\begin{tabular}{lc}
\hline Extract/fraction & $\begin{array}{c}P . \text { falciparum } \\
\mathrm{IC}_{50}(\mu \mathrm{g} / \mathrm{mL})\end{array}$ \\
\hline Methanol extracts of roots & $>50.0$ \\
Chloroform fractions of roots & 10.5 \\
Ethanol extracts of leaves & $>50.0$ \\
Chloroform fractions of leaves & 35.8 \\
Water extracts of roots & $>50.0$ \\
Chloroquine diphosphate salt & 0.13 \\
\hline
\end{tabular}

of roots did not exhibit cytotoxicity to these normal human cells $\left(\mathrm{IC}_{50}>50 \mu \mathrm{g} / \mathrm{mL}\right)$. Doxorubicin exhibited an $\mathrm{IC}_{50}$ of ca. $1.1 \mu \mathrm{g} / \mathrm{mL}$ against MCR-5 fibroblast cells.

In vitro antiplasmodial activity - The methanol and ethanol extracts of roots and leaves, respectively, exhibited no in vitro antiplasmodial activity against the $\mathrm{K} 1$ strain of $P$. falciparum $\left(\mathrm{IC}_{50}>50 \mu \mathrm{g} / \mathrm{mL}\right)$. Liquid-liquid partitioning of these extracts provided chloroform fractions of the roots and the leaves exhibiting, respectively, moderate $\left(\mathrm{IC}_{50}=10.5 \mu \mathrm{g} / \mathrm{mL}\right)$ and low $\left(\mathrm{IC}_{50}=35.8 \mu \mathrm{g} / \mathrm{mL}\right)$ in vitro inhibitory activity against $P$. falciparum (Table I).

At different concentrations, amplexine (2) inhibited the in vitro growth of the blood forms of the human malaria parasite $P$. falciparum W-2 Indochina strain vs. untreated controls. Chloroquine was used as a positive control. From the dose-response curve it was possible to establish an $\mathrm{IC}_{50}$ of $7.1 \mu \mathrm{g} / \mathrm{mL}$ (Fig. 2).

In vivo antiplasmodial activity - Water extracts of the roots of $T$. grandiflora were the most active samples in vivo in $P$. berghei-infected mice in the Peters 4-day suppressive test. On day 5 after infection, water extract of the roots administered by mouth and subcutaneously was accompanied by the observation of $59 \%$ and $45 \%$ suppression, respectively, of $P$. berghei growth vs. untreated controls (Table II). Methanol extracts of the roots of $T$. grandiflora administered orally exhibited borderline moderate inhibitory activity (39\% suppression of $P$. berghei growth) on the fifth day after infection in $P$. berghei-infected mice, but by the seventh day this effect had decreased substantially (Table II). Low in vivo activities (24-27\% parasite suppression) were observed on day 5 for the methanol extracts of roots administered by subcutaneous injection and the ethanol extracts of leaves administered orally, but by day 7 the suppressive effects of these extracts was null. In general, mean survival times for $P$. berghei-infected mice which had received $T$. grandiflora extracts were equivalent to untreated controls (Table II).

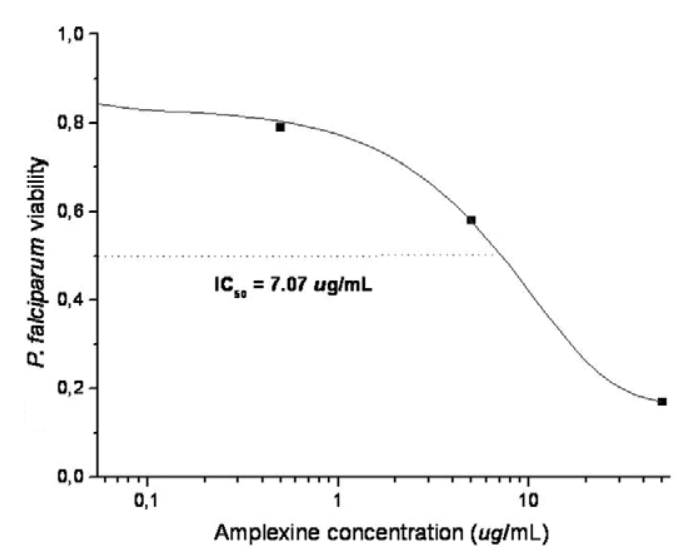

Fig. 2: dose-response curve for drug resistant Plasmodium falciparum W-2 strain in the presence of different concentrations of amplexine (djalonenol, tetrahydro-3-(hydroxymethyl)-4-[1-(hydroxymethyl)-2propenyl]-2H-pyran-2-one) in a representative experiment. $\mathrm{IC}_{50}$ : halfmaximal inhibitory concentration. 


\section{DISCUSSION}

As the Krettli group found for the extracts of the roots of a Tachia sp. from the Brazilian Amazon (Carvalho et al. 1991, Brandão et al. 1992), we found that the extracts of roots and leaves of T. grandiflora studied herein were inactive $\left(\mathrm{IC}_{50}>50 \mu \mathrm{g} / \mathrm{mL}\right)$ in vitro against $P$. falciparum (Table I). Through liquid-liquid partitioning of polar extracts, it was possible to obtain chloroform fractions of the roots and leaves. For the first time, in vitro antiplasmodial activity of a Tachia sp. against the human malaria parasite $P$. falciparum has been demonstrated (for these 2 chloroform fractions).

Little is known about the chemical composition of Tachia spp. Previously, Pio Corrêa (1926) described the isolation of a "bitter yellow glycoside (tachinine), bitter white, transparent crystalline plates (tachic acid) and rosettes of fine needles of a non-bitter alkaloid (caferanine)" from caferana (originally cited species: T. guianensis). The structures of these substances were not defined. Based on the diagnostic morphological characters of the drawing of caferana in Pio Correa's book, the species was either Tachia lancisepala or Tachia siwertii, both scientifically described only in 2005 (Struwe et al. 2005).

From the active root and leaf chloroform fractions of $T$. grandiflora the antiplasmodial tetra-oxygenated xanthone decussatin (1) and the rare seco-iridoid aglycone amplexine (2) were, respectively, isolated (Pohlit et al. 2012). Tetra-oxygenated xanthones like 1 are commonly isolated from gentians and seco-iridoids are also isolated from gentians. However, seco-iridoids generally occur as glycosides (Jensen \& Schripsema 2002).

Decussatin (1), has been previously isolated from Swertia alata C.B. Clarke (Gentianaceae) and has been shown by Karan et al. (2005) to have an in vitro protective effect against malaria parasites. In general, hydroxyxanthones such as 1 act through a parasite specific mechanism of action by blocking haemozoin formation in the $P$. falciparum digestive vacuole through binding to haeme in soluble haeme-xanthone complexes (Riscoe et al. 2005).
In the present work, amplexine (2) isolated from the leaves of T. grandiflora inhibited the growth of the blood stages of the W-2 strain of $P$. falciparum in vitro. Amplexine (2) is the dihydroxy monoterpene aglycone of the secoiridoid 1-O- $\beta$-D-glucopyranosylamplexine that was first isolated from the leaves of Anthocleista amplexicaulis Baker (Gentianaceae) (Rasoanaivo et al. 1994) and later from the stems of Anthocleista djalonensis A. Chev. (Onocha et al. 1995). Interestingly, in Madagascar, a leaf decoction of A. amplexicaulis is used as a remedy for malaria (Rasoanaivo et al. 1994). This is the first report on the antiplasmodial activity of terpenoid 2. Interestingly, terpenes arrest $P$. falciparum development by inhibiting the biosynthesis of polyprenylated (terpenoid) primary metabolites such as dolichols, ubiquinones and menaquinones during the growth of $P$. falciparum parasites within infected red blood cells (Goulart et al. 2004). The presence of antiplasmodial compounds 1 and 2 in T. grandiflora is interesting given the widespread traditional use of this plant in the treatment of malaria in the Amazon Region.

The Krettli group collected a Tachia sp. (originally cited species: T. guianensis) in the Brazilian Amazon in São Félix do Xingú, state of Pará (Carvalho et al. 1991, Carvalho \& Krettli 1991, Brandão et al. 1992, Krettli et al. 2001). Root infusions were prepared according to traditional practice and administered by mouth to $P$. bergheiinfected mice at doses of 100,500 and $1,000 \mathrm{mg} / \mathrm{kg} / \mathrm{day}$ in the 4-day suppressive test. The inhibition obtained was ca. $40 \%$ vs. controls. Based on the known distributions of Tachia spp, it is likely that the plant studied by the Krettli group was either T. grandiflora, the very rare $T$. siwertii Struwe, Kinkade \& Maas, or maybe even Tachia occidentalis Maguire and Weaver. The in vivo activity of T. grandiflora in $P$. berghei-infected mice herein, together with the Krettli et al.'s (2001) results points to the antimalarial potential of caferana (Tachia spp) infusions (Table II).

Extracts and isolated natural products that inhibit P. falciparum in vitro often may have little or no effect

TABLE II

In vivo suppression of Plasmodium berghei in infected mice and average mouse survival after oral and subcutaneous treatment with $500 \mathrm{mg} / \mathrm{kg}$ /day of extracts of Tachia grandiflora in the Peters 4-day suppressive test

Parasite inhibition

$(\%)$

\begin{tabular}{|c|c|c|c|c|c|c|}
\hline \multirow[b]{3}{*}{ Sample } & & \multirow{2}{*}{\multicolumn{2}{|c|}{$\begin{array}{l}\text { Average survival } \\
\text { time } \pm \mathrm{SD}\end{array}$}} \\
\hline & \multicolumn{2}{|c|}{ Oral } & \multicolumn{2}{|c|}{ Subcutaneous } & & \\
\hline & Day 5 & Day 7 & Day 5 & Day 7 & Oral & Subcutaneous \\
\hline Root water extract & 59 & 24 & 45 & 0 & $24 \pm 3$ & $22 \pm 2$ \\
\hline Root methanol extract & 39 & 11 & 27 & 0 & $21 \pm 2$ & $20 \pm 3$ \\
\hline Leaf ethanol extract & 24 & 0 & 6 & 0 & $19 \pm 3$ & $22 \pm 1$ \\
\hline Chloroquine, $10 \mathrm{mg} / \mathrm{kg} /$ day & 99 & 98 & 99 & 100 & $>40$ & $>40$ \\
\hline Control, blank & 0 & 0 & 0 & 0 & $20 \pm 5$ & $22 \pm 3$ \\
\hline
\end{tabular}

SD: standard deviation. 
against $P$. berghei in vivo. This was observed for the isolated natural product 4-nerolidylcatechol that in general was active against $P$. falciparum strains in vitro, but only provided a suppressive effect on $P$. berghei in mice at high dose $(600 \mathrm{mg} / \mathrm{kg} /$ day) (Rocha e Silva et al. 2011). On the other hand, the alkaloids ellipticine, olivacine and cryptolepine are active both in vitro against $P$. falciparum $\left(\mathrm{IC}_{50}=0.35-1.4 \mu \mathrm{M}\right)$ and in vivo against $P$. berghei in infected mice (10-100 mg/kg/day) (Rocha e Silva et al. 2012). The lack of in vitro antimalarial activity observed for polar extracts of T. grandiflora studied herein and the Tachia sp. studied by Krettli et al. (2001) mean that these extracts contain substances that mask, suppress or dilute the in vitro activity of antimalarial components that are present in these extracts and concentrated during the fractionation step that led to the preparation of the active chloroform fractions. Future work on the chemical composition of Tachia spp should feature an initial extraction step followed by liquid-liquid partitioning of the extract to generate simple fractions of increasing polarity that should be assayed both for in vivo activity against $P$. berghei and in vitro activity in a bioguided process.

Despite the affirmation in Pio Corrêa (1926) that caferana plants present toxicity. The extracts and fractions of roots and leaves of $T$. grandiflora were not toxic to human fibroblasts in vitro $\left(\mathrm{IC}_{50}>50 \mu \mathrm{g} / \mathrm{mL}\right)$. Interestingly, Pohlit et al. (2007) found that fractions of leaf extracts of T. grandiflora were cytotoxic in vitro to five tumour cell lines $\left(\mathrm{IC}_{50}=4.1-25.4 \mu \mathrm{g} / \mathrm{mL}\right)$. Thus, there is a selective in vitro cytotoxic effect of the leaf extracts and fractions against the faster growing tumour cells than against normal (human fibroblast) cells. Selective cytotoxicity and genotoxicity are common features of many drugs, including antimalarials such as artesunate and artemether. Mota et al. (2011) demonstrated that artesunate is cytotoxic and genotoxic to human lymphocytes and Alcântara et al. (2013) demonstrated that artemether was more cytotoxic to human lymphocytes than to gastric cancer cell line PG100. More studies on the in vitro cytotoxicity, mutagenicity and genotoxicity of $T$. grandiflora against different normal human cells and in vivo studies in animal models are needed to evaluate the potential pharmacological applications of $T$. grandiflora in humans.

\section{ACKNOWLEDGEMENTS}

To Prof Dr Antoniana Ursine Krettli, whose ethnobotanic surveys in the Brazilian Amazon and dedication to the experimental evaluation of Amazonian antimalarial plants have had a direct bearing on this study and been an inspiration to the authors for more than a decade, to Prof Maria das Graças Lins Brandão (UFMG, Brazil), for information and clarifications regarding publications co-authored by her, and to Tatiane Cristina Mesquita da Silva and to Etienne Louis Jacques Quignard, for collaboration.

\section{REFERENCES}

Ahmed SA, Gogal Jr RM, Walsh JE 1994. A new rapid and simple non-radioactive assay to monitor and determine the proliferation of lymphocytes: an alternative to $\left[{ }^{3} \mathrm{H}\right]$ thymidine incorporation assay. J Immunol Methods 15: 211-224.

Alcântara DD, Ribeiro HF, Cardoso PC, Araújo TM, Burbano RR, Guimarães AC, Khayat AS, de Oliveira Bahia M 2013. In vitro evaluation of the cytotoxic and genotoxic effects of artemether, an antimalarial drug, in a gastric cancer cell line (PG100). $J$ Appl Toxicol 33: 151-156.

Andrade-Neto VF, Pohlit AM, Pinto ACS, Silva ECC, Nogueira KL, Melo MRS, Henrique MC, Amorim RCN, Silva LFR, Costa MRF, Nunomura RCS, Nunomura SM, Alecrim WD, Alecrim MGC, Chaves FCM, Vieira PPR 2007. In vitro inhibition of Plasmodium falciparum by substances isolated from Amazonian antimalarial plants. Mem Inst Oswaldo Cruz 102: 359-365.

Brandão MGL, Grandi TSM, Rocha EMM, Sawyer DR, Krettli AU 1992. Survey of medicinal plants used as antimalarials in the Amazon. J Ethnopharmacol 36: 175-182.

Carvalho LH, Brandão MGL, Santos-Filho D, Lopes JLC, Krettli AU 1991. Antimalarial activity of crude extracts from Brazilian plants studied in vivo in Plasmodium berghei-infected mice and in vitro against Plasmodium falciparum in culture. Braz J Med Biol Res 24: 1113-1123.

Carvalho LH, Krettli AU 1991. Antimalarial chemotherapy with natural products and chemically defined molecules. Mem Inst Oswaldo Cruz 86 (Suppl. II): 181-184.

Dua VK, Ojha VP, Roy R, Joshi BC, Valecha N, Devi CU, Bhatnagar MC, Sharma VP, Subbarao SK 2004. Anti-malarial activity of some xanthones isolated from the roots of Andrographis paniculata. J Ethnopharmacol 95: 247-251.

Goulart HR, Kimura EA, Peres VJ, Couto AS, Duarte FAA, Katzin AM 2004. Terpenes arrest parasite development and inhibit biosynthesis of isoprenoids in Plasmodium falciparum. Antimicrob Agents Chemother 48: 2502-2509.

Jensen SR, Schripsema J 2002. Chemotaxonomy and pharmacology of gentianaceae. In L Struwe, V Albert (eds.), Gentianaceae Systematics and natural history, Cambridge University Press, Cambridge, p. 573-631.

Karan M, Bhatnagar S, Wangtak P, Vasisht K 2005. Phytochemical and antimalarial studies on Swertia alata Royale. Acta Horticulturae 675: 139-145.

Krettli AU, Andrade-Neto VF, Brandão MGL, Ferrari WMS 2001. The search for new antimalarial drugs from plants used to treat fever and malaria or plants randomly selected: a Review. Mem Inst Oswaldo Cruz 96: 1033-1042.

Lambros C, Vanderberg JP 1979. Synchronization of Plasmodium falciparum erythrocytic stages in culture. J Parasitol 65: 418-420.

Maguire B, Weaver Jr RE 1975. The neotropical genus Tachia (Gentianaceae). J Arnold Arbor 56: 103-125.

Milliken W 1997. Plants for malaria plants for fever: medicinal species in Latin America - a bibliographic survey, The Royal Botanic Gardens, Kew, 121 pp.

Mors WB, Rizzini CT, Pereira NA 2000. Medicinal plants of Brazil, RA de Filipps (ed.), Medicinal plants of the world 6, Reference Publication, Algonac, $501 \mathrm{pp}$.

Mota TC, Cardoso PC, Gomes LM, Vieira PC, Corrêa RM, Santana PD, Miranda MS, Burbano RM, Bahia MO 2011. In vitro evaluation of the genotoxic and cytotoxic effects of artesunate, an antimalarial drug, in human lymphocytes. Environ Mol Mutagen 52: $590-594$.

Onocha AP, Okorie AD, Connolly DJ, Roycroft DS 1995. Monoterpene diol, iridoid glucoside, and dibenzo- $\alpha$-pyrone from Anthocleista djalononensis. Phytochemistry 40: 1183-1189.

Peters W, Kinkade MP, Pohlit AM, Struwe L 2005. Tachia field guide, Rutgers University/National Institute on Amazon Research, New Brunswick/Manaus, 1 pp. 
Pio Corrêa M 1926. Dicionário de plantas úteis do Brasil e das exóticas cultivadas, Vol. 1, Imprensa Nacional, Rio de Janeiro, 391 pp.

Pohlit AM, Quignard ELJ, Nunomura SM, Tadei WP, Hidalgo AF, Pinto ACS, Santos EVM, Morais SKR, Saraiva RCG, Ming LC, Alecrim AM, Ferraz AB, Pedroso ACS, Diniz EV, Finney EK, Gomes EO, Dias HB, Souza KS, Oliveira LCP, Don LC, Queiroz MMA, Henrique MC, Santos M, Lacerda Jr OS, Pinto PS, Silva SG, Graça YR 2004. Screening of plants found in Amazonas state, Brazil, for activity against Aedes aegypti larvae. Acta Amazonica 34: 97-105.

Pohlit AM, Santos EVM, Silva TCM, Morais SKR, Nunomura SM, Struwe L 2012. A rare secoiridoid monoterpene and a xanthone from Tachia grandiflora Maguire \& Weaver. Biochem Syst Ecol 44: 267-269.

Pohlit AM, Tigre RF, Cavalcanti BC, Moraes MO, Costa-Lotufo LV, Moraes MEA, Santos EVM, Morais SKR, Nunomura SM, Pessoa CO 2007. Cytotoxic fractions from the leaves of Tachia grandiflora. Pharm Biol 45: 429-433.

Quignard ELJ, Pohlit AM, Nunomura SM, Pinto ACS, Santos EVM, Morais SKR, Alecrim AM, Pedroso ACS, Cyrino BRB, Melo CS, Finney EK, Gomes EO, Souza KS, Oliveira LCP, Don LC, Silva LFR, Queiroz MMA, Henrique MC, Santos M, Pinto PS, Silva SG 2003. Screening of plants found in Amazonas state for lethality towards brine shrimp. Acta Amazonica 33: 93-104.

Rasoanaivo P, Nicoletti M, Multari G, Palazzino G, Galeffi C 1994. Secoiridoids and related monoterpenes of Anthocleista amplexicaulis. Fitoterapia 65: 38-43.

Rieckmann KH, Sax LJ, Campbell GH, Mrema JE 1978. Drug sensitivity of Plasmodium falciparum. An in vitro microtechinique. Lancet 1: 22-23.

Riscoe M, Kelly JX, Winter R 2005. Xanthones as antimalarial agents: discovery, mode of action and optimization. Curr Med Chem 12: 2539-2549.

Rocha e Silva LFR, Montoia A, Amorim RCN, Melo MRS, Henrique MC, Nunomura SM, Costa MRF, Andrade-Neto VF, Costa DS, Dantas GR, Lavrado J, Moreira R, Paulo A, Pinto AC, Tadei WP, Zacardi RS, Eberlin MN, Pohlit AM 2012. Comparative in vitro and in vivo antimalarial activity of the indole alkaloids ellipticine, olivacine, cryptolepine and a synthetic cryptolepine analog. Phytomedicine 20: 71-76.

Rocha e Silva LFR, Pinto ACS, Pohlit AM, Quignard ELJ, Vieira PPR, Tadei WP, Chaves FCM, Samonek JFV, Lima AJL, Costa MRF, Alecrim MGC, Andrade-Neto VF 2011. In vivo and in vitro antimalarial activity of 4-nerolidylcatechol. Phytother Res 25: $1181-1188$

Schmidt TJ, Khalid SA, Romanha AJ, Alves TMA, Biavatti MW, Brun R, Costa FB, de Castro SL, Ferreira VF, de Lacerda MVG, Lago JHG, Leon LL, Lopes NP, Amorim RCN, Niehues M, Ogungbe IV, Pohlit AM, Scotti MT, Setzer WN, Soeiro MNC, Steindel M, Tempone AG 2012a. The potential of secondary metabolites from plants as drugs or leads against protozoan neglected diseases Part I. Curr Med Chem 19: 2128-2175.

Schmidt TJ, Khalid SA, Romanha AJ, Alves TMA, Biavatti MW, Brun R, Costa FB, de Castro SL, Ferreira VF, de Lacerda MVG, Lago JHG, Leon LL, Lopes NP, Amorim RCN, Niehues M, Ogungbe IV, Pohlit AM, Scotti MT, Setzer WN, Soeiro MNC, Steindel M, Tempone AG 2012b. The potential of secondary metabolites from plants as drugs or leads against protozoan neglected diseases Part II. Curr Med Chem 19: 2176-2228.

Schultes RE, Raffauf RF 1990. The healing forest: medicinal and toxic plants of the northwest Amazonia, Dioscorides Press, Oregon, $500 \mathrm{pp}$.

Silva AF, Sampaio PTB, Pohlit AM 2006. Propagação de Tachia grandiflora por estaquia de galhos. Rev Fitos (ALANAC) 2: 89-93.

Struwe L, Kinkade MP, Maas PJM 2005. Two new Brazilian species of Tachia (Gentianaceae: Helieae). Blumea 50: 457-462.

Tchamo DN, Dijoux-Franca MG, Mariotte AM, Tsamo E, Daskiewicz JB, Bayet C, Barron D, Conseil G, Di Pietro A 2000. Prenylated xanthones as potential P-glycoprotein modulators. Bioorg Med Chem Lett 10: 1343-1345.

WHO - World Health Organization 2001. In vitro micro-test (Mark III) for the assessment of the response of Plasmodium falciparum to chloroquine, mefloquine, quinine, amodiaquine, sulfadoxine/ pyrimetamine and artemisinin. Available from: whqlibdoc.who. int/hq/2001/a76873.pdf. 